\title{
Microscopic Analysis of the Myocardial Bridges and their Relationship with Atheromatous Plaque
}

\author{
Análisis Microscópico de los Puentes Miocárdicos y su Relación con la Placa Ateromatosa
}

Fabián A. Gómez ${ }^{1}$; Pedro L. Forero ${ }^{1,2, \dagger}$ \& Luis E. Ballesteros ${ }^{1}$

GÓMEZ, F. A.; FORERO, P. L. \& BALLESTEROS, L. E. Microscopic analysis of the myocardial bridges and their relationship with atheromatous plaque. Int. J. Morphol., 39(1):70-76, 2021.

SUMMARY: Most histopathological studies have reported that the segment of the coronary artery below the myocardial bridge does not present atheromatous plaque, while the segment proximal to the myocardial bridge may have it. The aim of this study was to evaluate the microscopic environment of myocardial bridges. This descriptive study was carried out with 60 hearts of individuals who underwent autopsy at the National Institute of Legal Medicine and Forensic Sciences in Bucaramanga-Colombia. For each specimen, the coronary arteries and their branches were dissected, removing the subepicardial adipose tissue to identify the myocardial bridges and obtain histological sections of the compromised arterial branches. The presence of myocardial bridges was observed in 22 hearts ( 36.7 $\%$ ) with a length of $17.31+4.41 \mathrm{~mm}$ and a thickness of $904.57+312.27 \mathrm{~mm}$. The coronary vessel caliber at the prepontine level was $246.57+49.33 \mathrm{~mm}$ and was significantly higher than in the pontine $(188.92+60.55 \mathrm{~mm})$ and postpontin $(190.40+47 \mathrm{~mm})$ segments ( $\mathrm{p}=0.001$ for both values). Atheromatous plaque was observed in the prepontine segment in 12 cases (46.15\%) and in 8 samples (30.76 $\%)$ at the pontine level, but in this segment, there was slight damage to the vascular endothelium, or phase I level. The thickness of the tunica intima in the cases with atheromatous plaque was $15.68+13.39 \mathrm{~mm}$ and that of the plaque-free segments was $5.10+4.40 \mathrm{~mm}$ $(\mathrm{p}=0.005)$, and in the pontine segment the overlying periarterial adipose tissue had a thickness of $72.01+69.44 \mathrm{~mm}$, which was higher than the other three locations ( $\mathrm{p}=0.005)$. The morphometry of the perivascular fat pad and the presence of phase I atheromatous plaque are the main contributions of this study to the histology of myocardial bridges.

KEY WORDS: perivascular adipose tissue,tunica intima, myocardial bridge, atheromatous plaque, endothelium.

\section{INTRODUCTION}

Myocardial bridges (MB) were defined for the first time as segments of the coronary arteries temporarily submerged in the myocardium by Reyman in 1737; since then they have been described in anatomical, physiological, biochemical, and imaging studies. (Shinjo et al., 1999; Silaghi et al., 2011). The MB have an embryological origin without gender differences, and in terms of their incidence, they remain a still controversial research problem. An interpretation of anatomical or pathological variation of the MB presence depends on contrasting different pathophysiological points of view (Lozano et al., 2002; Silaghi et al.). Some authors have pointed out that MB generate atheroma, but others describe them as useful in the prevention of atheroma. Likewise, there are those who have postulated MB as simple variations and criticize their surgical management for considering their manipulation as a risk factor (Silaghi et al.).
The MB are structures formed by the cardiac muscle, located on the coronary vessels and their branches (arteries and veins). They have been singled out as inducing ischemia in the external musculature distal to them, due to compression of the blood vessels during myocardial contraction, but only a long MB can cause a notable impact on the circulation (Saidi et al., 2010; De Giorgio et al., 2014).The incidence of MB varies between $0.5-85 \%$ in both angiographic and anatomical studies (Ferreira Jr. et al., 1991; Kantarci et al., 2006; Ballesteros Acuña et al., 2009).

The length, depth and location in one or several arterial branches are morphological characteristics of MB that can affect the expression of various ischemic or arrhythmic pathologies of the heart. It is important to bear in mind that $\mathrm{MB}$ in a high percentage are asymptomatic, because compensatory mechanisms are present, such as the

\footnotetext{
${ }^{1}$ Department of Basic Sciences. School of Medicine. Universidad Industrial de Santander, Cra 32 \# 29-31. 68002. Bucaramanga, Colombia.

${ }^{2}$ National Instituteof Legal Medicine and ForensicSciences- Bucaramanga, Colombia.

$\dagger$ Rest in peace, he died from Covid-19 on August 19, 2020.
} 
presence of collateral branches that arise from the prepontine segment and contribute to the irrigation of adjacent territories. Likewise, when they are added to the relatively adverse anatomical substrate, factors such as atheromatosis can trigger clinical events such as angina, arrhythmias, or even sudden death in situations such as stress and exercise (Rozenberg et al., 2004).

It has recently been suggested that the perivascular tissue below MB is histopathologically remarkable in longitudinal sections of the anterior interventricular branch (AIB). This perivascular space contains fatty tissue that can function as a coronary mattress that cushions the compression made by the MB during systole (Saidi et al.). Histopathological studies have determined that the AIB segment below the MB is free from atherosclerosis, but the AIB segment proximal to the MB is susceptible to it (Iuchi et al., 2013; Verhagen et al., 2013). The influence or relationship of periarterial adipose tissue in the suppression of atherosclerosis in the AIB segment below the MB has not yet been examined. Furthermore, it is clarified that the qualitative and morphometric characterization of this tissue has been very generic (Saidi et al.; Iuchi et al.).

Previous reports (Burke et al., 2001; Schwartz et al., 2009) have indicated that atheromatous plaque (AP) rupture and erosion represent the majority of cases of intracoronary thrombosis and microembolization. The severity of stenosis among the most disrupted lesions was reported as greater than $75 \%$ of the lumen in across-sectional area (Narula et al., 2013).

By evaluating the microscopic features of $\mathrm{MB}$ and its environment we contribute to a better understanding of the pathophysiological processes that develop around these variant structures of the coronary circulation.

\section{MATERIAL AND METHOD}

This cross-sectional descriptive study was carried out in the Morphology laboratory of the Health Faculty of the Industrial University of Santander, with 60 hearts obtained from unclaimed corpses who underwent an autopsy at the Institute of Legal Medicine and Forensic Sciences of Bucaramanga. The hearts of individuals were taken in a period of 8 months.Procedures were in accordance with the Scientific Research Ethics Committee of the Industrial University of Santander (CIENCI-UIS, in Spanish, minute number 08-2016) and comply with Resolution 008430 of 1993, Decree 2164 of 1992 and Law 10 of 1990 of the Colombian Ministry of Health and the principles of the Declaration of Helsinki.
After collection, the hearts were subjected to a fixation process with $5 \%$ formaldehyde solution. Subsequently, dissection of the coronary arteries was performed, removing the subepicardial adipose tissue to identify the MB, making histological cuts at this level involving boththe coronary vessel and its adjacent tissues.Likewise, sections of the prepontine and postpontine segments were obtained by looking for the presence of AP in them. The presence of this lesion was described according to the criteria of Fernandez et al. (2003) like this:Phase I,intimal hyperplasia (adherence of fatty streaks in the tunica intima of the blood vessel); Phase II,vulnerable plaque (it has a lipid center surrounded by a fibrous capsule that presents risk of rupture); Phases III and IV,rupture of the plaque (rupture of the vulnerable plaque towards the lumen of the vessel, with the formation of thrombi); and Phase V,fibrous plaques (totally fibrotic and calcified plaques, which can produce stenosis of blood vessels). The sections were stained with Hematoxylin Eosin (to evaluate thickness of adipose tissue, characteristics of muscle fibers, AP, and characteristics of vascular tunics). In addition, using a lens with a micrometric count, a qualitative and quantitative evaluation of the tunics of the vessels was performed, at the pre, pontine and postpontine levels of perivascular adipose tissue and myocardial fibrosis.

In MB specimens, their morphometric characteristics (length, thickness of the suprapontine myocardial tissue and determination of the size of the compromised vessel) were recorded at the pre, pontine and postpontine level. Additionally, the specific location of this morphological expression was recorded.

Statistical analysis. Descriptive statistics and graphics were performed using SPSS 20 software (SPSS, Chicago, IL, USA) and Microsoft Excel 2013. Descriptive statistics were calculated for each morphometric parameter and the Kolmogorov Smirnov test for normality was performed for each sample. Since the sample was less than 30 , in the case of quantitative variables, the non-parametric Mann-Whitney $\mathrm{U}$ test was used. Statistical significance of $\mathrm{p}<0.05$ was considered. Categorical variables were expressed as a percentage. In comparing qualitative dichotomy variables, such as the presence of fibrosis and the color of the nucleus of the cardiac fiber, a chi-square test was used. When comparing mutually dependent quantitative variables, such as the thickness of adipose tissue at each of the poles at the periarterial level, the non-parametric Friedman test was used. When the quantitative variables followed the normal distribution for the groups of segments, the ANOVA test was used. $\mathrm{T}$ tests were used to compare the different parameters of the coronary vessels in the presence or absence of AP. Data were expressed as averages and standard deviations for all measured lengths and angles. 


\section{RESULTS}

The presence of MB was observed in 22 hearts (36.7 $\%$ ), and two MB were found in four specimens. The arterial branch with the highest presentation of this muscle band was the AIB with 20 cases $(76.9 \%)$, located between the upper and middle segments of this arterial branch. Likewise, in four samples (15.4\%), MB was observed in the diagonal branch and in two cases $(7.7 \%)$ in the circumflex branch, being significantly lower than found in the AIB $(p<0.001)$. The average length of MB was $17.31+4.41 \mathrm{~mm}$.

In the prepontine and postpontine segments with no AP, the tunica intimawith an endothelium with clear chromatin nuclei was observed, supported by a loose matrix of collagen fibers and the presence of an internal elastic lamina. The tunica media, or middle layer is made up of mature smooth muscle fibers, arranged in bands and separated by thin layers of connective tissue fibers. The adventitia,or tunica externa had collagen fibers, principally of Type I collagen, and elastic fibers, which are surrounded by the venous and arterial capillaries of the vasa vasorum and the loose periarterial connective tissue made up of bands of collagen fibers, accompanied by small amounts of mature adipocytes made up of clear cytoplasm and eccentric nuclei rounded with clear chromatins.

In pontine segment, the immersed arterial wall was observed between two mature cardiomyocytesstrips, with central nuclei and eosinophilic cytoplasm. These cells were arranged in bundles separated by thin collagen fibers, completely covering the vascular structure. The thickness of suprapontine myocardial band was $904.57+312.27 \mu \mathrm{m}$. At this level, light colored nuclei myocardial fibers $(92.3$ $\%)$ predominated over those of a deep colored core $(\mathrm{p}=0.013)$. Fibrosis was observed among the bundles of cardiomyocytes, with an area of $501.66+202.5 \mathrm{~mm} 2$ on the right side of the vessel and $317.77+236.66 \mathrm{~mm} 2$ at the level of its lower pole. Additionally, in this segment, a "mattress or pad" of perivascular fatty tissue was observed between the adventitia of the coronary vessel and cardiomyocytes, consisting of mature adipocytes with abundant clear cytoplasm and eccentric nuclei of pale chromatins, arranged in small groups and divided by thin fibrous septa (Fig. 1). This space was surrounded by nerve branches and arterial and venous capillary structures (Figs. 1 and 2). The thickness of periarterial adipose tissue in the upper pole was $72.01+69.44 \mu \mathrm{m}$, while in the underlying plane it was $34.19+21.27 \mu \mathrm{m}(\mathrm{p}=0.005)$ (Table I).

In the different segments where AP was observed, the wall of coronary arterial vessel presented slight fragmentation
Table I. Morphometric arrangement of periarterial adipose tissue at the pontine level in cases of myocardial bridges.

\begin{tabular}{ccccc}
\hline Case & $\begin{array}{c}\text { Superior } \\
\text { pole }(\mu \mathrm{m})\end{array}$ & $\begin{array}{c}\text { Inferior } \\
\text { pole }(\mu \mathrm{m})\end{array}$ & $\begin{array}{c}\text { Right side } \\
(\mu \mathrm{m})\end{array}$ & $\begin{array}{c}\text { Left side } \\
(\mu \mathrm{m})\end{array}$ \\
\hline 1 & 16 & 15 & 26 & 9 \\
$2 \mathrm{a}$ & 44 & 12 & 40 & 37 \\
$2 \mathrm{~b}$ & 19 & 11 & 19 & 12 \\
3 & 84 & 39 & 30 & 24 \\
4 & 87 & 35 & 60 & 170 \\
5 & 45 & 25 & 38 & 20 \\
6 & 84 & 39 & 30 & 27 \\
7 & 210 & 52 & 46 & 25 \\
8 & 15 & 33 & 67 & 53 \\
9 & 95 & 85 & 111 & 122 \\
10 & 83 & 57 & 54 & 35 \\
$11 \mathrm{a}$ & 250 & 62 & 54 & 32 \\
$11 \mathrm{~b}$ & 17 & 15 & 145 & 152 \\
12 & 12.5 & 30 & 62.5 & 55 \\
13 & 17 & 15 & 15 & 9 \\
14 & 83 & 35 & 30 & 22 \\
15 & 88 & 45 & 63 & 92 \\
16 & 42 & 10 & 47 & 35 \\
$17 \mathrm{a}$ & 55 & 35 & 50 & 81 \\
$17 \mathrm{~b}$ & 5 & 7 & 15 & 6 \\
18 & 92 & 80 & 105 & 145 \\
19 & 16 & 35 & 62 & 49 \\
20 & 8 & 10 & 17 & 8 \\
$21 \mathrm{a}$ & 18 & 14 & 15 & 12 \\
$21 \mathrm{~b}$ & 227 & 48 & 39 & 35 \\
22 & 160 & 45 & 65 & 57 \\
\hline & & & &
\end{tabular}

of the endothelium of the tunica intima with elongated nuclei and intense chromatins, which were supported by a hyaline and lipid matrix, surrounded by a fibrous band that increased the thickness of the tunica intima. Loss of the internal elastic membrane and participation of smooth muscle fibers of the tunica media involved in the formation of fibrous matrix of the vessel were observed. Adventitia showed no alterations. At the prepontine level, 12 cases $(46.2 \%)$ with AP were located, of which plaque was observed in phase I in 10 (83.3 $\%$ ) and phase II in 2 cases (16.7 \%) (Fig. 3). At the pontine level, AP was found in 8 cases $(30.8 \%)$ and in $100 \%$ it was in phase I (Fig. 1). In the postpontine segment, AP was observed in 4 cases $(15.4 \%$ ), of which $50 \%$ occurred in phase I and 50 $\%$ in phase II. At the prepontine level, the thickness of the tunica intima was significantly greater in cases where the presence of AP was present ( $\mathrm{p}=0.008$ ) (Fig. 3). Furthermore, the tunica media was significantly thicker in cases where AP was in phase II than in phase $\mathrm{I}(\mathrm{p}=0.040)$. At the postpontine level, the thickness of the tunica intima was also significantly greater in cases where there was presence of AP $(p=0.004)$ (Table I). We found that the thickness of intimate tunic was significantly greater in cases where there was presence of AP $(\mathrm{p}=0.050)$ (Table II). 


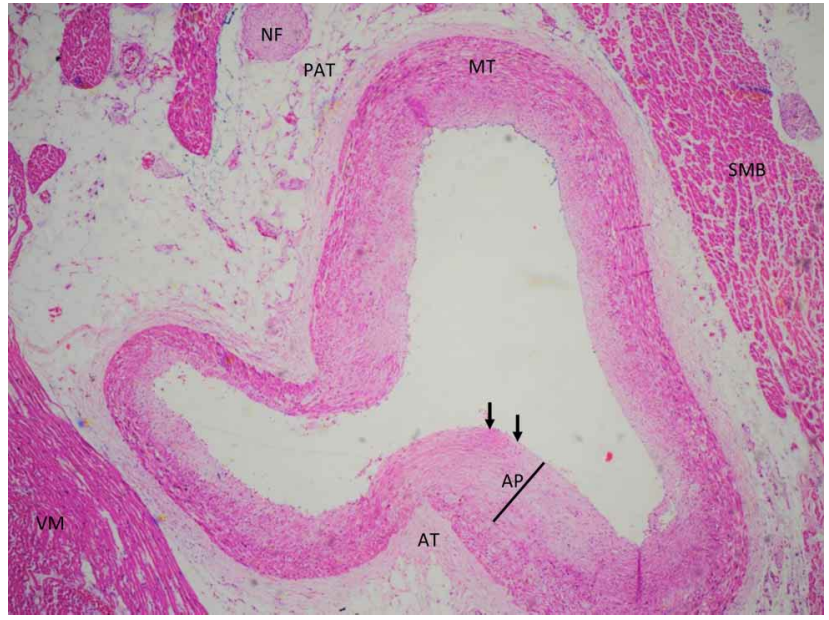

Fig. 1. Pontine segment of the anterior interventricular branch. Note the thickness of the atheroma plaque (AP), which increases the thickness of the intimate tunic (arrows) and detaches the vascular endotheliumin the blood vessel compressed by the myocardial bridge. MT: middle tunic; AT: adventitia tunic; PAT: periarterial adipose tissue; SMB: suprapontin myocardial band; VM: ventricular myocardium; NF: nerve fiber.

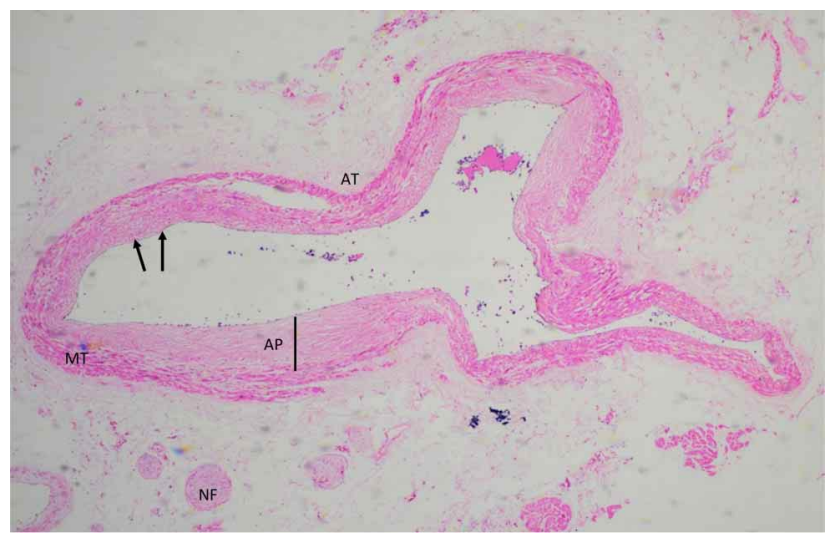

Fig. 3. Prepontine segment of the anterior interventricular branch. Note the thickness of the atheroma plaque (AP), which increases the thickness of the intimate tunic (arrows). MT: middle tunic; AT: adventitia tunic; NF: nerve fiber.

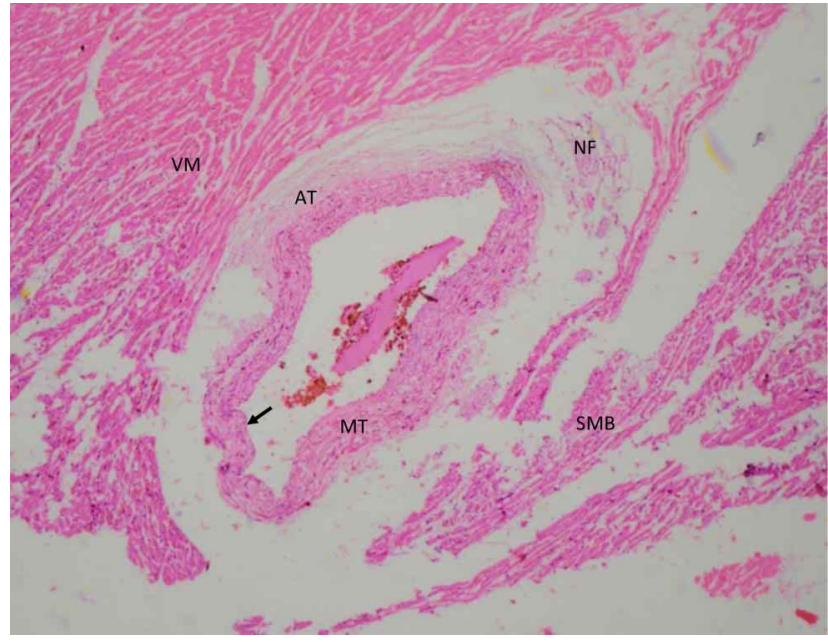

Fig. 2. Pontine segment of the anterior interventricular branch. In this case, no atheroma plaque (AP) is observed in the blood vessel affected by the myocardial bridge. MT: middle tunic; AT: adventitia tunic; SMB: suprapontin myocardial band; VM: ventricular myocardium; NF: nerve fiber; (arrow): intimate tunic.

In a joint analysis of the three arterial segments, it was found that the caliber of the prepontine segment was significantly greater than pontine and postpontine segments ( $p=0.001$ for both values). Additionally, in the prepontine segment the thickness of tunica intima of the coronary vessel was significantly greater than in postpontine segment $(\mathrm{p}=0.025)$ and likewise the thickness of the tunica media in prepontine segment was significantly greater than in the other two segments ( $\mathrm{p}=0.011$ and $\mathrm{p}=0.005$ respectively). At the adventitia tunic level, there were no significant differences in the thickness of the vessel between the segments (Fig. 4). Regarding the behavior of AP in coronary vessel, we observed that caliber of the vessel wall and the tunica intima is greater when there was plaque ( $\mathrm{p}=0.001$ and $\mathrm{p}=0.005$ respectively). In these cases, the thickness of the middle and adventitia layers did not show significant differences (Table II).
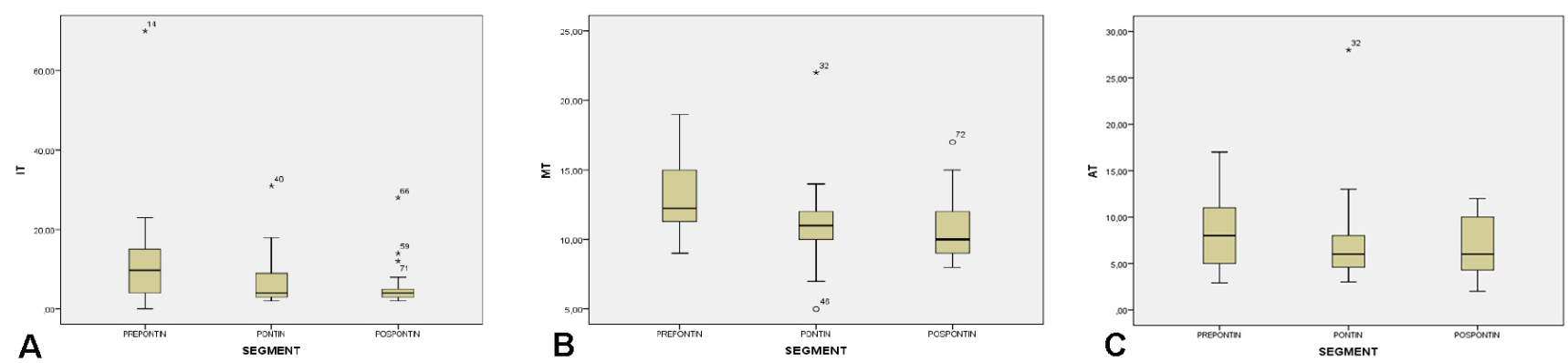

Fig. 4. Statistical behavior of the intimate tunic (IT), middle tunic (MT) and adventitia tunic (AT) in each of the segments of the coronary vessel when myocardial bridges are present. 
Table II. Morphometry of the vascular segments of the branches of the coronary arteries in the presence of atheroma plaque and myocardial bridges.

\begin{tabular}{|c|c|c|c|c|c|c|}
\hline & Segment & $\begin{array}{c}\text { Atheroma } \\
\text { plaque radio } \\
(\mu \mathrm{m} / \mathrm{SD})\end{array}$ & $\begin{array}{c}\text { Blood vessel } \\
\text { caliber }(\mu \mathrm{m} / \mathrm{SD})\end{array}$ & $\begin{array}{c}\text { Intimate } \\
\text { tunic }(\mu \mathrm{m} / \mathrm{SD})\end{array}$ & $\begin{array}{c}\text { Middle } \\
\text { tunic }(\mu \mathrm{m} / \mathrm{SD})\end{array}$ & $\begin{array}{c}\text { Adventitia } \\
\text { tunic }(\mu \mathrm{m} / \mathrm{SD})\end{array}$ \\
\hline \multirow[t]{4}{*}{$\begin{array}{l}\text { Atheroma } \\
\text { plaque }\end{array}$} & Prepontine & $\begin{array}{c}13.12 \\
(3)\end{array}$ & $2,505.6(366.9)$ & $17.62(16.78)$ & $13.22(2.85)$ & $\begin{array}{c}8.07 \\
(3.20)\end{array}$ \\
\hline & Pontine & $\begin{array}{l}15.18 \\
(2.2)\end{array}$ & $1,845(560.1)$ & $13.25(9.64)$ & $11.52(2.17)$ & $\begin{array}{c}7 \\
(3.66)\end{array}$ \\
\hline & Postpontin & $\begin{array}{l}13.75 \\
(4.19)\end{array}$ & $1,768.7(626.2)$ & $14.75(9.63)$ & $11(2.44)$ & $\begin{array}{c}8.75 \\
(3.20)\end{array}$ \\
\hline & Prepontine & - & $2,439.1(576.9)$ & $8.02(7.36)$ & $13.23(2.94)$ & $\begin{array}{c}8.41 \\
(4.21)\end{array}$ \\
\hline \multirow{2}{*}{$\begin{array}{l}\text { Without } \\
\text { atheroma } \\
\text { plaque }\end{array}$} & Pontine & - & $1,908.8(639.3)$ & 4.35 (2.49) & 10.77 (3.29) & $\begin{array}{c}7.58 \\
(5.85)\end{array}$ \\
\hline & Postpontin & - & $1,928.6(450.3)$ & $3.86(1.58)$ & $10.79(2.10)$ & $\begin{array}{c}6.19 \\
(2.54)\end{array}$ \\
\hline
\end{tabular}

\section{DISCUSSION}

The findings from this work regarding the histological characterization of $\mathrm{MB}$ and its relationship with AP significantly enrich the existing information on this topic.

In humans, MB occurs in most cases in the AIB and, through coronary angiography, computed tomography, and direct anatomical studies, they have reported their frequency in a wide range of $0.5 \%-87.5 \%$ (Ballesteros Acuña et al.; Iuchi et al.; Almeida et al., 2019). It has been reported that the length of MB is between 14.6-19.9 mm and the caliber of coronary vessel at the prepontine level is $2.17-2.76 \mathrm{~mm}$, at the pontine level of 1.26-2.08 $\mathrm{mm}$ and at the postpontine level of 1.67-1.98 mm (Lima et al., 2002; Ballesteros Acuña et al.; Javadzadegan et al., 2019). Our findings were in a medium range in relation to the incidence and length of $\mathrm{MB}$ reported in previous studies. We agree with the studies carried out in other population groups that the AIB is the coronary vessel with the highest incidence of MB. In this study, the values of the caliber of coronary vessels, at the level of the three reference segments, were found in a medium range from previous reports.

Also in previous studies, it has been indicated that the perivascular space located below the MB, contains adipose tissue that can function as a "coronary mattress" that cushions the compression made by the MB during systole (Saidi et al.; Iuchi et al. 2013). Said tissue may also be involved in a local stimulation that reduces atherosclerosis processes through active adipokines functions secreted from periarterial adipose tissue (Silaghi et al.; Iuchi et al.).In agreement with some authors (Saidi et al.; Verhagen et al.; Iuchi et al.) alsoin this study, adipose tissue was found in the perivascular space around the arterial segment below the MB, accompanied by fibers nerve and small blood vessels in all specimens evaluated. Additionally, the histomorphometry performed on this perivascular tissue showed a greater thickness at the level of the superior pole of the vessel, which confirms its condition as a shock absorber of the pressure exerted on the vessels during myocardial contraction in the systolic phase.

In addition, fibrotic changes in the perivascular myocardium have been observed at this level, which can reduce the compression force of the MB, which would influence the absence of atherosclerosis (Iuchi et al.). In our research we found the presence of fibrous tissue bundles around the entire coronary vessel and mainly in the lower pole.Similarly, it has been reported (Verhagen et al.) that the prepontine and postpontine tunica intima of the coronary vessel is thicker than pontine segment. These descriptions agree with what was reported in our study where a thicker tunica intima was found in the segments outside the MB.

Previous studies confirm that presence of atherosclerotic changes in the vascular segment located below and distal to $\mathrm{MB}$ are minor or absent, but in the segment proximal to $\mathrm{MB}$ the incidence of $\mathrm{AP}$ was higher, reported in a range of 20-75.6\% (Angelini et al., 2002; Verhagen et al.; Iuchi et al.). Our study is concordant with the presence of AP in three segments and the values found in our series (46.1\% $\mathrm{AP}$ in the prepontine segment) are in a medium range compared to that reported in other studies. For pontine segment, we found AP in $30.7 \%$, higher than those indicated by other authors, but these were typified in phase I with little alteration of the coronary vessel (Angelini et al.; Iuchi et al.). These findings reinforce the hypothesis that the compression force made by the MB during systole would be the reason 
why atherosclerosis does not appear or is scarce in the vascular segment below the MB, but in turn this compression over the vessel overflows the physiological tolerance of the endothelium in the prepontine segment that triggers the changes that lead to the formation of AP. It is noted that some studies report that $\mathrm{MB}$ does not influence the presence of $\mathrm{AP}$ in prepontine and postpontine segments (Lubarsky et al., 2007; Bayrak et al., 2009). The marked difference among different studies in relation to the incidence of AP in vascular segments related to the presence of $\mathrm{MB}$, can be explained by the age of the subjects evaluated, size of the samples and the biological characteristics surrounding lipid metabolism of the different population groups.

Presence of MB as a cause of angina or myocardial infarction has been reported in some cases (Saidi et al.). These patients did not show evidence of atherosclerosis at autopsy, with MB being the only cause of death (Diaz-Widmann et al., 2003; Saidi et al.), confirming the low presence of AP at the pontine level, possibly due to the mattress of adipose tissue that is decisive for the low incidence of $\mathrm{MB}$ as a cause of death. However, in our study it was found that the highest percentage of atherosclerosis was observed in the prepontine segment, in the presence of MB, possibly caused by the compression made by the bridge over the coronary vessel. In addition, we also found a slight percentage of AP in the postpontine segment.

MB has generally been described as benign, but when associated with atherosclerosis, vasospasm, and chest pain, they become a cause of sudden death (Kawai et al., 2020; van der Velde et al., 2020). This confirms the close relationship between the presentation of $\mathrm{MB}$ and $\mathrm{AP}$, especially in patients with a high risk of heart failure.

\section{CONCLUSIONS}

AP was found mainly at the prepontine level, but in turn an important percentage of this plaque was found at pontine level, with the exception that it only occurred in phase I, with slight damage to the coronary vascular endothelium.

Periarterial adipose tissue was found in $100 \%$ of the samples with MB and mainly in the upper pole, in addition to the presence of fibrous bundles in the perivascular space, components that would avoid excessive compression of the coronary vessel by the bridge.

ACKNOWLEDGEMENTS. To the National Institute of Legal Medicine and Forensic Sciences of Bucaramanga, Colombia for the donation of specimens studied in this research.
GÓMEZ, F. A.; FORERO, P. L. \& BALLESTEROS, L. E. Análisis microscópico de los puentes miocárdicos y su relación con la placa ateromatosa. Int. J. Morphol., 39(1):70-76, 2021.

RESUMEN: La mayoría de los estudios histopatológicos han reportado que el segmento de la arteria coronaria debajo del puente miocárdico no presenta placa ateromatosa, mientras que el segmento proximal al puente miocárdico puede tenerla. El objetivo de este estudio fue evaluar el entorno microscópico de los puentes miocárdico. Este estudio descriptivo se realizó con 60 corazones de individuos a quienes se les práctico autopsia en el Instituto Nacional de Medicina Legal y Ciencias Forenses de BucaramangaColombia. Para cada espécimen se realizó disección de las arterias coronarias y sus ramas, eliminando el tejido adiposo subepicárdico para identificar los puentes miocárdicos y obtener secciones histológicas de las ramas arteriales comprometidas. Se observó presencia de puentes miocárdicos en 22 corazones $(36,7 \%)$ con una longitud de $17.31+4.41 \mathrm{~mm}$ y un espesor de $904.57+312.27$ $\mathrm{mm}$. El calibre del vaso coronario a nivel prepontino fue $246.57+$ $49.33 \mathrm{~mm}$ y fue significativamente mayor que en el segmento pontino $(188.92+60.55 \mathrm{~mm})$ y pospontino $(190.40+47 \mathrm{~mm})$ ( $\mathrm{p}=0.001$ para ambos valores). Se observó placa ateromatosa en el segmento prepontino en 12 casos $(46.15 \%)$ y en 8 muestras (30.76 $\%)$ al nivel pontino, pero en este segmento, correspondieron a fase I, con ligero daño en el endotelio vascular. El espesor de la túnica íntima en los casos con placa ateromatosa fue de $15.68+13.39$ $\mathrm{mm}$ y de los segmentos libres de placa fue $5.10+4.40 \mathrm{~mm}$ $(\mathrm{p}=0.005)$ y en el segmento pontino el tejido adiposo periarterial suprayacente presento un espesor de $72.01+69.44 \mathrm{~mm}$, el cual fue mayor a las otras tres ubicaciones $(\mathrm{p}=0.005)$. La morfometría de la almohadilla adiposa perivascular y la presencia de placa ateromatosa en fase I son los principales aportes de este estudio a la histología de los puentes miocárdicos.

PALABRAS CLAVE: Tejido adiposo perivascular; Túnica íntima; Puente miocárdico; Placa ateromatosa; Endotelio.

\section{REFERENCES}

Almeida, A. R.; Pereira, A. R.; Morgado, G.; Loureiro, M. J.; Ferreira, F.; Cruz, I.; Lopes, L. R. \& Pereira, H. Three-vessel myocardial bridging: A possible cause of myocardial stunning. Rev. Port. Cardiol., 38(3):225.e1-225.e5, 2019.

Angelini, P.; Velasco, J. A. \& Flamm, S. Coronary anomalies: incidence, pathophysiology, and clinical relevance. Circulation, 105(20):2449-54, 2002.

Ballesteros Acuña, L. E.; Ramírez Aristeguieta, L. M. \& Tellez, S. B. Descrição morfológica e implicações clínicas de pontes miocárdicas: um estudo anatômico em colombianos. Arq. Bras. Cardiol., 92(4):242$8,2009$.

Bayrak, F.; Degertekin, M.; Eroglu, E.; Guneysu, T.; Sevinc, D.; Gemici, G.; Mutlu, B. \& Aytaclar, S. Evaluation of myocardial bridges with 64slice computed tomography coronary angiography. Acta Cardiol., 64(3):341-6, 2009.

Burke, A. P.; Kolodgie, F. D.; Farb, A.; Weber, D. K.; Malcom, G. T.; Smialek, J. \& Virmani, R. Healed plaque ruptures and sudden coronary death: evidence that subclinical rupture has a role in plaque progression. Circulation, 103(7):934-40, 2001 
De Giorgio, F.; Grassi, V. M.; Polacco, M.; Pascali, V. L.; d'Aloja, E. \& Arena, V. Myocardial bridging and sudden cardiac death: Is the actual classification exhaustive? Int. J. Cardiol., 172(3):E383-4, 2014.

Diaz-Widmann, J.; Cox, S. L. \& Roongsritong, C. Unappreciable myocardial bridge causing anterior myocardial infarction and postinfarction angina. South Med. J., 96(4):400-2, 2003.

Fernandez, G. C.; Tardáguila, F. M.; López, C. T.; Velasco, M.; San Miguel, P. \& de la Fuente, A. Physiopathology of the atherosclerotic plaque and imaging methods findings. Radiología, 45(3):107-14, 2003.

Ferreira Jr., A. G.; Trotter, S. E.; Konig Jr., B.; Décourt, L. V.; Fox, K. \& Olsen, E. G. Myocardial bridges: morphological and functional aspects. Br. Heart J., 66(5):364-7, 1991.

Iuchi, A.; Ishikawa, Y.; Akishima-Fukasawa, Y.; Fukuzawa, R.; Akasaka, Y. \& Ishii, T. Association of variance in anatomical elements of myocardial bridge with coronary atherosclerosis. Atherosclerosis, 227(1):153-8, 2013.

Javadzadegan, A.; Moshfegh, A.; Mohammadi, M.; Askarian, M. \& Mohammadi, M. Haemodynamic impacts of myocardial bridge length: A congenital heart disease. Comput. Methods Programs Biomed., 175:25-33, 2019.

Kantarci, M.; Duran, C.; Durur, I.; Alper, F.; Onbas, O.; Gulbaran, M. \& Okur, A. Detection of myocardial bridging with ECG-gated MDCT and multiplanar reconstruction. AJR Am. J. Roentgenol., 186(6 Suppl. 2):S391-4, 2006

Kawai, H.; Ohta, M.; Motoyama, S.; Hashimoto, Y.; Takahashi, H.; Muramatsu, T.; Sarai, M.; Narula, J. \& Ozaki, Y. Computed tomographic angiography-verified myocardial bridge and invasive angiography-verified left anterior descending coronary artery vasospasm. JACC Cardiovasc. Interv., 13(1):144-6, 2020.

Lima, V. J. M.; Cavalcanti, J. S. \& Tashiro, T. Myocardial bridges and their relationship to the anterior interventricular branch of the left coronary artery. Arq. Bras. Cardiol., 79(3):219-22, 2002.

Lozano, I.; Baz, J. A.; Palop, R. L.; Pinar, E.; Picó, F.; Valdés, M.; Larman, M. \& Martínez Ubago, J. L. Long-term prognosis of patients with myocardial bridge and angiographic milking of the left anterior descending coronary artery. Rev. Esp. Cardiol., 55(4):359-64, 2002.

Lubarsky, L.; Gupta, M. P. \& Hecht, H. S. Evaluation of myocardial bridging of the left anterior descending coronary artery by 64-slice multidetector computed tomographic angiography. Am. J. Cardiol., 100(7):1081-2, 2007.

Narula, J.; Nakano, M.; Virmani, R.; Kolodgie, F. D.; Petersen, R.; Newcomb, R.; Malik, S.; Fuster, V. \& Finn, A. V. Histopathologic characteristics of atherosclerotic coronary disease and implications of the findings for the invasive and noninvasive detection of vulnerable plaques. J. Am. Coll. Cardiol., 61(10):1041-51, 2013.

Reyman, H. C. Dissertatis de Vasis Cordis Propriis. $7^{\text {th }}$ ed. Goettingae, A. Vandenhoeck, 1737.

Rozenberg, V. D.; Nepomnyashchikh, L. M. Pathomorphology and pathogenic role of myocardial bridges in sudden cardiac death. Bull. Exp. Biol. Med., 138(1):87-92, 2004.

Saidi, H.; Ongeti, W. K. \& Ogengo, J. Morphology of human myocardial bridges and association with coronary artery disease. Afr. Health Sci., 10(3):242-7, 2010.

Schwartz, R. S.; Burke, A.; Farb, A.; Kaye, D.; Lesser, J. R.; Henry, T. D. \& Virmani, R. Microemboli and microvascular obstruction in acute coronary thrombosis and sudden coronary death: relation to epicardial plaque histopathology. J. Am. Coll. Cardiol., 54(23):2167-73, 2009.

Shinjo, S. K.; Prates, N. E. V. B.; Oba, S. M.; Sampaio, L. O. \& Nader, H. B. Distribution and composition of glycosaminoglycans in the left human coronary arterial branches under myocardial bridge. Atherosclerosis, 143(2):363-8, 1999.

Silaghi, A. C.; Pais, R.; Vallea, A. \& Mironiuc, A. Epicardial adipose tissue and relationship with coronary artery disease. Cent. Eur. J. Med., 6(3):251-62, 2011. van der Velde, N.; Huurman, R.; Yamasaki, Y.; Kardys, I.; Galema, T. W.; Budde, R. P. J.; Zijlstra, F.; Krestin, G. P.; Schinkel, A. F.; Michels, M.; et al. Frequency and significance of coronary artery disease and myocardial bridging in patients with hypertrophic cardiomyopathy. Am. J.Cardiol., 125(9):1404-12, 2020

Verhagen, S. N.; Rutten, A.; Meijs, M. F.; Isgum, I.; Cramer, M. J.; van der Graaf, Y. \& Visseren, F. L. J. Relationship between myocardial bridges and reduced coronary atherosclerosis in patients with angina pectoris. Int. J. Cardiol., 167(3):883-8, 2013.

\author{
Corresponding author: \\ Fabián A. Gómez: \\ Department of Basic Sciences \\ School of Medicine \\ Universidad Industrial de Santander \\ Cra 32 \# 29-31. 68002 \\ Bucaramanga \\ COLOMBIA
}

Email: falegom@uis.edu.co.

Received: 25-08-2020

Accepted: 17-09-2020 